\title{
Screening of Protease Inhibitory Activity in Aqueous Extracts of Marine Invertebrates from Cuban Coast
}

\author{
Lidice González¹, Rafael E. Sánchez ${ }^{1}$, Laritza Rojas ${ }^{1}$, Isel Pascual1, \\ Rossana García-Fernández ${ }^{1}$, María A. Chávez ${ }^{1}$ Christian Betzel ${ }^{*}$ \\ ${ }^{1}$ Centro de Estudio de Proteínas, Facultad de Biología, Universidad de La Habana, La Habana, Cuba \\ ${ }^{2}$ Institute of Biochemistry and Molecular Biology, Department of Chemistry, University of Hamburg, Hamburg, \\ Germany \\ Email: *Christian.Betzel@uni-hamburg.de
}

Received 28 January 2016; accepted 3 April 2016; published 6 April 2016

Copyright (C) 2016 by authors and Scientific Research Publishing Inc.

This work is licensed under the Creative Commons Attribution International License (CC BY). http://creativecommons.org/licenses/by/4.0/

c) (i) Open Access

\section{Abstract}

Protease inhibitors have been isolated from many variable sources; however, the need to identify and characterize new molecules has increased with the discovery of new therapeutic targets and the lack of specificity of already identified compounds with inhibitory activity. The goal of this work was to search for inhibitory activity against four proteolytic enzymes already recognized as therapeutic targets: human neutrophil elastase, dipeptidyl peptidase IV, subtilisin from Bacillus licheniformis and cathepsin $\mathrm{K}$ in selected marine invertebrates from the Caribbean Sea. A systematic screening was carried out with selected aqueous extracts belonging to 20 species from seven different phyla: Annelida, Bryozoa, Chordata, Cnidaria, Equinodermata, Mollusca and Porifera, all collected at the coast of Havana (Cuba). All extracts showing initial inhibitory activity were characterized in terms of IC $_{50}$ values and specific inhibitory activity (SIA). Model enzymes were used in the case of human neutrophil elastase (porcine pancreatic elastase) and cathepsin $K$ (papain) for the screening and all positive results were confirmed by testing toward the therapeutic targets. Ten extracts were identified showing inhibitory activity against human neutrophil elastase, for which the most promising values were obtained for Nerita peloronta. Only one extract, Bunodosoma granulifera, showed inhibitory activity against dipeptidyl peptidase IV with rather poor values of $\mathrm{IC}_{50}$ and SIA. Seven extracts showed inhibitory activity against $B$. licheniformis subtilisin with very good $\mathrm{IC}_{50}$ and SIA values for Lissodendorix isodyctialis, Cenchritis muricatus, and $\mathbf{N}$. peloronta. Finally, eight extracts were positive for cathepsin $\mathrm{K}$ with almost similar parameters values among them. All these results confirmed the richness and potential of the marine invertebrate's fauna and indicated new promising sources for the identification of natural compounds with potential application in therapeutics.

${ }^{*}$ Corresponding author.

How to cite this paper: González, L., Sánchez, R.E., Rojas, L., Pascual, I., García-Fernández, R., Chávez, M.A. and Betzel, C. (2016) Screening of Protease Inhibitory Activity in Aqueous Extracts of Marine Invertebrates from Cuban Coast. American Journal of Analytical Chemistry, 7, 319-331. http://dx.doi.org/10.4236/ajac.2016.74030 


\section{Keywords}

\section{Target Proteases, Marine Organisms, Protease Inhibitors, Screening}

\section{Introduction}

Proteases represent about 2\% of the genes in humans as well as in infectious organisms [1] [2]. These enzymes are involved in a broad range of physiological processes of vital importance, including defense mechanisms in response to infection, activation of prohormones and zymogens, release of active peptides, assembly of viruses and proliferation/invasion processes of bacteria and parasites [1] [3]. Many examples show the functional role of proteases in the appearance or development of diseases [2] [4], e.g. the serine proteases human neutrophil elastase (HNE), subtilisins, dipeptidylpeptidase-IV (DPPIV) and papain-like proteases, such as cathepsin K. The former, which is involved in pulmonary emphysema, rheumatoid arthritis and cystic fibrosis, is released from human polymorphonuclear leukocytes in response to inflammatory stimuli and it is responsible for the degradation of connective tissue proteins [5] [6]. Subtilisins are involved in invasion processes of many pathogenic parasites and bacteria, such as Plasmodium falciparum and the nosocomial pathogen Stenotrophomonas maltophilia, [7] [8]. Dipeptidylpeptidase-IV is implicated in human systemic conditions, such as diabetes mellitus, cancer and inflammatory diseases [9] [10]. The cysteine protease cathepsin K, highly expressed by osteoclasts, causes degradation of type I collagen during bone resorption and it is considered as a main factor in bone disorders such as osteoporosis [11] [12]. Therefore, all these enzymes constitute potential therapeutic targets for the treatment of the diseases where they are involved.

Inhibition is one of the main molecular control mechanisms regulating the proteolytic activity. Therefore protease inhibitors (PI) have been isolated and characterized in the past and till now. They have synthetized from the most variable sources and have shown to be useful in biochemistry, biotechnology and biomedicine [2]. However, the discovery of new proteases with high physiological importance has increased the requirements to search and identify new inhibitory molecules with high potency and selectivity [8] [13]-[16]. In this regard, natural inhibitors have shown good properties to be used in biological systems, as they have mostly high stability at physiological conditions and low toxicity. On the other hand, natural sources are an infinite stock of bioactive molecules and structures, as a result of several millions years of evolution [17]-[19].

Marine invertebrates have been already recognized as one of the most valuable natural sources of biomolecules. They contain an intangible number of proteases and inhibitors, used for feeding and self-defense system against predators [19]-[22]. Many compounds with therapeutic potentialities have been isolated from these organisms, although most of them are poorly studied [17]. Cuban coasts have a remarkable variety of marine invertebrates, which allows screening of biological activity straight from natural sources as a first step to identify new molecules with potential properties such as toxins, antimicrobial peptides, proteases and inhibitors [23]-[28]. The data presented here describe systematic screening experiments to identify inhibitory activities applying twenty aqueous extracts of selected marine invertebrates against four proteases of therapeutic relevance.

\section{Material and Methods}

\subsection{Materials}

Enzymes: porcine pancreatic elastase (PPE) (EC 3.4.21.36), human neutrophil elastase (HNE) (EC 3.4.21.37), subtilisin A from Bacillus licheniformis (EC 3.4.21.62) and human dipeptidyl peptidase IV (DPPIV) (EC 3.4.14.5) were purchased from Sigma (USA). Papain from Carica papaya (3.4.22.2) was acquired from Roche (USA) and human cathepsin K (EC3.4.22.38) from Merck (Germany). DPPIV from porcine kidney was purified and kindly donated by Dr. Isel Pascual, at Faculty of Biology, University of Havana, Cuba [29]. Synthetic substrates: succinyl-trialanine-4-nitroanilide (Suc-Ala-Ala-Ala-pNA), 3-Methoxysuccinyl-alanyl-alanyl-prolyl-valine-4-nitroanilide (MeOSuc-Ala-Ala-Pro-Val-pNA), Succinyl-alanyl-alanyl-prolyl-phenylalanine-4-nitroanilide (Suc-ala-ala-pro-phe-pNA), glycyl-proline-4-nitroanilide (Gly-Pro-pNA.HCl), benzyloxycarbonyl-phenyl-arginine-4-nitroanilide (Z-phe-arg-pNA.HCl) were purchased from Bachem (Germany). 


\subsection{Preparation and Clarification of Animal Aqueous Extracts}

The invertebrate organisms (Table 1) were collected from different localizations of the Cuban coast area by specialists of the Cuban National Institute of Oceanology, taking into account the protective measures for these species in the area. The specimens were washed with distilled water and cut in small pieces. The aqueous extracts were prepared as follow: the organisms were homogenized in distilled water at a 1:2 proportion (w/v) using a blender (10 sec for 5 repeated cycles). The homogenized suspension obtained was centrifuged at 15,000 $\times$ $g$ for $45 \mathrm{~min}$ at $4^{\circ} \mathrm{C}$ and the supernatant was filtered on fiberglass [25]. Clarified extracts were obtained by heating in a thermal bath for $30 \mathrm{~min}, 60^{\circ} \mathrm{C}$. This process was followed by a fast cooling and centrifugation at 15,000 $\times g$ for $45 \min$ at $4^{\circ} \mathrm{C}$.

\subsection{Determination of Protein Concentration}

Protein and peptide concentrations in the extracts were determined by measuring the absorbance at $280 \mathrm{~nm}$ in GENESYS 10S UV-Vis spectrophotometer (Thermo Scientific) and using an extinction coefficient $\left(\xi_{280 \mathrm{~mm}}^{0.1 \%}\right)$ of 1 [30]. Concentrations of the enzymes used in the kinetic assays were calculated applying their reported extinction coefficients [31].

\subsection{Inhibitory Activities}

The enzymatic activity for PPE $\left(2.7 \times 10^{-8} \mathrm{M}\right)$ and HNE $\left(1.0 \times 10^{-7} \mathrm{M}\right)$ was determined using the specific substrates Suc-Ala-Ala-Ala-pNA $\left(0.7 \mathrm{mM}, 0.6 \mathrm{~K}_{\mathrm{M}}\right)$ [32] and MeOSuc-Ala-Ala-Pro-Val-pNA $\left(0.14 \mathrm{mM}, 1 \mathrm{~K}_{\mathrm{M}}\right)$ [33], respectively. Subtilisin A $\left(0.9 \times 10^{-7} \mathrm{M}\right)$ was measured using Suc-Ala-Ala-Pro-Phe-pNA $\left(0.12 \mathrm{mM}, 1 \mathrm{~K}_{\mathrm{M}}\right)$ [33]. Porcine DPPIV $\left(1.6 \times 10^{-7} \mathrm{M}\right)$ and human DPPIV $\left(4.34 \times 10^{-7} \mathrm{M}\right)$ activities were both tested using Gly-PropNA $\left(0.14 \mathrm{mM}, 1 \mathrm{~K}_{\mathrm{M}}\right)$ [34], whereas papain $\left(4.34 \times 10^{-8} \mathrm{M}\right)$ and cathepsin $\mathrm{K}\left(0.92 \times 10^{-8} \mathrm{M}\right)$ activities were

Table 1. Screening of 20 marine invertebrate extracts for EPP, subtilisin, DPPIV and papain inhibitory activities.

\begin{tabular}{|c|c|c|c|c|c|c|}
\hline & Species & Phylum & $\mathrm{PPE}$ & Subtilisin & DPPIV & Papain \\
\hline 1. & Hermodice carunculata & Annelida & & & & \\
\hline 2. & Bugula plumosa & Bryozoa & & & & \\
\hline 3. & Ecteinascidia turbinata & Chordata & & & & \\
\hline 4. & Ascidia sidneyensis & Chordata & & & & \\
\hline 5. & Diplosoma listerianum & Chordata & + & & & \\
\hline 6. & Ascidia furticosa & Chordata & & & & \\
\hline 7. & Phallusia nigra & Chordata & & & & \\
\hline 8. & Bunodosoma granulifera & Cnidaria & + & + & + & \\
\hline 9. & Condylactis gigantea & Cnidaria & + & + & & + \\
\hline 10. & Stichodactyla helianthus & Cnidaria & + & & & + \\
\hline 11. & Plexaura homomalla & Cnidaria & + & & & + \\
\hline 12. & Physalia physalis & Cnidaria & & & & + \\
\hline 13. & Zoanthus sociatus & Cnidaria & & & & \\
\hline 14. & Echinaster equinophorus & Equinodermata & & + & & \\
\hline 15. & Holothuria mexicana & Equinodermata & + & & & \\
\hline 16. & Isostochopus badionotus & Equinodermata & + & + & & + \\
\hline 17. & Nerita peloronta & Mollusca & + & + & & + \\
\hline 18. & Lima scabra & Mollusca & & & & \\
\hline 19. & Cenchritis muricatus & Mollusca & + & + & & + \\
\hline 20. & Lissodendorix isodyctialis & Porifera & + & + & & + \\
\hline
\end{tabular}


determined using z-Phe-Arg-pNA $\left(0.14 \mathrm{mM}, 1 \mathrm{~K}_{\mathrm{M}}\right)$ [35], (0.025 mM, $\left.1 \mathrm{~K}_{\mathrm{M}}\right)$ [36], respectively. All enzyme and substrate concentrations above referred correspond to the assay.

The inhibitory activities were determined using a GENESYS 10S UV-Vis spectrophotometer, by measuring the residual enzymatic activity at $25^{\circ} \mathrm{C}$ after incubation with each extract for $10 \mathrm{~min}$. The assay mixtures contained substrate, enzyme, extract and the corresponding activity buffers in a final volume of $1 \mathrm{~mL}$. Cleavage of substrates by the enzymes was detected by measuring the increase of the absorbance at $405 \mathrm{~nm}$ every $15 \mathrm{~s}$ during 3 min.

The inhibitory activity (IA) against each enzyme was measured at five different protein concentrations. The measurements were made by triplicate and the inhibitory activities were calculated in linear zones of the curves obtained employing the Equation (1):

$$
I A(\mathrm{U} / \mathrm{mL})=\left(\frac{\Delta A b s}{\Delta t_{\text {control }}}-\frac{\Delta A b s}{\Delta t_{\text {sample }}}\right) \cdot \frac{1}{\xi} \cdot \frac{V_{\text {assay }}}{V_{\text {sample }}} \cdot d i l
$$

$\Delta A b s / \Delta t_{\text {control }}$ and $\Delta A b s / \Delta t_{\text {sample: }}$ change in absorbance per time unit in the control and sample assay, respectively; $V_{\text {sample: }}$ extract volume; $V_{\text {assay }}$ : assay volume; $\xi$ : extinction coefficient of the product $p$-nitroaniline $(\xi=8.8 \times$ $\left.10^{-3} \mathrm{~mol}^{-1} \cdot \mathrm{L} \cdot \mathrm{cm}^{-1}\right)$.

To calculate the specific inhibitory activity (SIA), IA values were divided by the total protein concentration of each extract. Moreover, the residual enzymatic activity for each extract concentration was determined, in order to obtain the corresponding $\mathrm{IC}_{50}$ value (half maximal inhibitory concentration) by adjusting the experimental data to the $\mathrm{IC}_{50}$ equation [37] using the software GraphPad Prism5.0 (GraphPad Software, Inc., USA) [38]. The $\mathrm{IC}_{50}$ equation was included in the GraphPad software and implemented as a User-Defined-Equation. After entering the equation, the rule to compute initial values for the parameter $\mathrm{IC}_{50}$ was defined as Value of $\mathrm{X}$ at $\mathrm{Y}$ mid. There was not applied any constraints or weighting method.

The extracts that did not show inhibition for a ratio [Io]/[Eo] > 2000 were considered as negative. The concentration ratio [Io]/[Eo] was calculated in the assay by using the extract concentration producing the highest inhibition and [Eo] was assumed as total initial protein concentration.

Inhibition of the human enzymes HNE and cathepsin $\mathrm{K}$ was only analyzed with those extracts showing doseresponse inhibitory activities and low $\mathrm{IC}_{50}$ values toward the related proteases PPE and papain, respectively.

\subsection{Proteolytic Activity of Extracts}

To discard inhibition due to the presence of proteases in the extracts analyzed, proteolytic activity was evaluated against the different chromogenic substrates (specific for each type of enzyme). These assays were performed under the same conditions described above, but without adding the corresponding enzyme used as the control in the inhibitory assays.

\section{Results}

\subsection{Screening of Protease Inhibitors}

The inhibitory activities of 20 aqueous extracts prepared from marine invertebrates against four proteases were evaluated at different protein concentrations (Table 1).

\subsubsection{Inhibition of Elastases}

As observed, 10 of the 20 applied extracts show inhibitory activity against PPE. The highest SIA values were obtained for Stichodactyla helianthus, Lissodendorix isodyctialis, Holothuria mexicana and Nerita peloronta (Table 2(a)). The SIA calculated for the last one was remarkably higher compared to the others $(444.4 \mathrm{mU} / \mathrm{mg})$. These extracts also showed the lowest $\mathrm{IC}_{50}$ values, with $N$. peloronta being again the most promising extract, considering the $\mathrm{IC}_{50}$ value of $1 \mu \mathrm{g} / \mathrm{mL}$. The concave behavior observed in the dose-response curves obtained for the active extracts against PPE (Figure 1(a)) is characteristic for a reversible inhibition [39]. Remarkably, the dose-response curve behavior obtained for the $N$. peloronta extract resembled a titration curve, thus suggesting the presence of tight binding or irreversible elastase inhibitors (Figure 1(b)). All positive extracts were also able to inhibit the enzymatic activity of HNE and $N$. peloronta was confirmed the most promising extract in terms of SIA (Table 2(b)). 
Table 2. (a) Results of the screening for EPP inhibitory activity in marine invertebrates; (b) HNE inhibitory activity in marine invertebrates.

(a)

\begin{tabular}{|c|c|c|c|c|}
\hline Species & $\begin{array}{c}\text { Protein } \\
\text { concentration } \\
(\mathrm{mg} / \mathrm{ml})\end{array}$ & $\begin{array}{l}\text { Inhibitory activity } \\
\qquad(\mathrm{mU} / \mathrm{ml})\end{array}$ & $\begin{array}{c}\text { Specific } \\
\text { inhibitory activity } \\
(\mathrm{mU} / \mathrm{mg})\end{array}$ & $\mathrm{IC}_{50}(\mathrm{mg} / \mathrm{ml})$ \\
\hline Bunodosoma granulifera & $51.2 \pm 1.2$ & $591.31 \pm 34.55$ & 11.55 & $0.29 \pm 0.02$ \\
\hline Stichodactyla helianthus & $26.4 \pm 0.78$ & $2445.07 \pm 123.16$ & 92.62 & $0.026 \pm 0.002$ \\
\hline Condylactis gigantea & $20.9 \pm 0.45$ & $467.82 \pm 23.87$ & 22.38 & $0.12 \pm 0.01$ \\
\hline Isostochopus badionotus & $13.56 \pm 0.79$ & $69.85 \pm 3.76$ & 5.15 & $0.78 \pm 0.04$ \\
\hline Cenchritis muricatus & $19.9 \pm 0.43$ & $429.15 \pm 25.42$ & 21.57 & $0.23 \pm 0.02$ \\
\hline Nerita peloronta & $8.72 \pm 0.64$ & $3875.16 \pm 254.21$ & 444.40 & $0.001 \pm 0.0006$ \\
\hline Lissodendorix isodyctialis & $4.98 \pm 0.73$ & $382.47 \pm 24.54$ & 76.80 & $0.049 \pm 0.004$ \\
\hline Plexaura homomalla & $96.4 \pm 0.26$ & $1093.63 \pm 215.39$ & 11.34 & $0.50 \pm 0.05$ \\
\hline Diplosoma listerianum & $11.1 \pm 0.45$ & $53.53 \pm 17.14$ & 4.86 & $0.47 \pm 0.04$ \\
\hline Holothuria mexicana & $1.5 \pm 0.36$ & $85.32 \pm 7.86$ & 56.88 & $0.064 \pm 0.007$ \\
\hline
\end{tabular}

(b)

\begin{tabular}{cccc}
\hline Species & $\begin{array}{c}\text { Protein concentration } \\
(\mathrm{mg} / \mathrm{ml})\end{array}$ & $\begin{array}{c}\text { Inhibitory activity } \\
(\mathrm{mU} / \mathrm{ml})\end{array}$ & $\begin{array}{c}\text { Specific } \\
\text { inhibitory activity } \\
(\mathrm{mU} / \mathrm{mg})\end{array}$ \\
\hline Bunodosoma granulifera & $51.2 \pm 1.2$ & 741.57 & 14.48 \\
Stichodactyla helianthus & $26.4 \pm 0.78$ & 3123.60 & 118.32 \\
Condylactis gigantea & $20.9 \pm 0.45$ & 612.36 & 29.30 \\
Isostochopus badionotus & $13.56 \pm 0.79$ & 66.29 & 4.89 \\
Cenchritis muricatus & $19.9 \pm 0.43$ & 1134.83 & 57.03 \\
Nerita peloronta & $8.72 \pm 0.64$ & 4314.61 & 494.79 \\
Lissodendorix isodyctialis & $4.98 \pm 0.73$ & 359.55 & 72.20 \\
Plexaura homomalla & $96.4 \pm 0.26$ & 1573.03 & 16.32 \\
Diplosoma listerianum & $11.1 \pm 0.45$ & 35.96 & 3.24 \\
Holothuria mexicana & $1.5 \pm 0.36$ & 92.13 & 61.42 \\
\hline
\end{tabular}

Data are means $(n=3) \pm$ S.D.

\subsubsection{Inhibition of Dipeptidyl Peptidase-IV (DPPIV)}

In contrast to PPE, which was inhibited by several extracts, only Bunodosoma granulifera showed inhibitory activity against porcine and human DPPIV. The specific activity, which was only determined against the porcine enzyme, was very low and the $\mathrm{IC}_{50}$ value, obtained from the dose-response curve (Figure 1(c)) was very high (Table 3), thus indicating that the inhibition activity is rather poor.

\subsubsection{Inhibition of Subtilisin}

As shown in Table 4, seven extracts showed inhibitory activity of subtilisin and according to their specific activities and $\mathrm{IC}_{50}$ values, the most promising extracts were Lissodendorix isodyctialis, Cenchritis muricatus, and Nerita peloronta. The dose-response curves for these extracts exhibited nearly a titration behavior suggesting the presence of tight binding inhibitors (Figure 1(d)). Other extracts, such as the echinoderms Echinaster equinophorus and Isostochopus badionotus, also showed strong inhibitory activities against subtilisin with high values of SIA. 


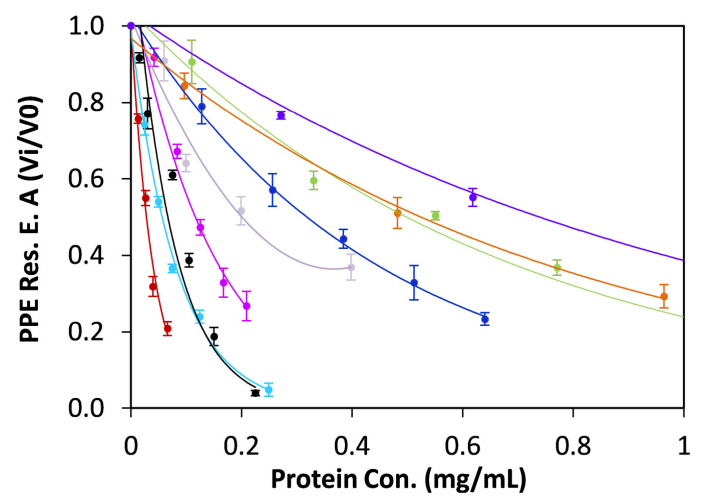

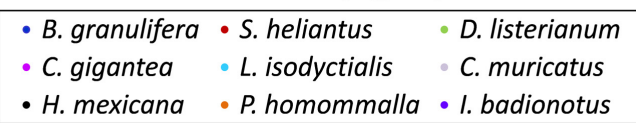

(a)

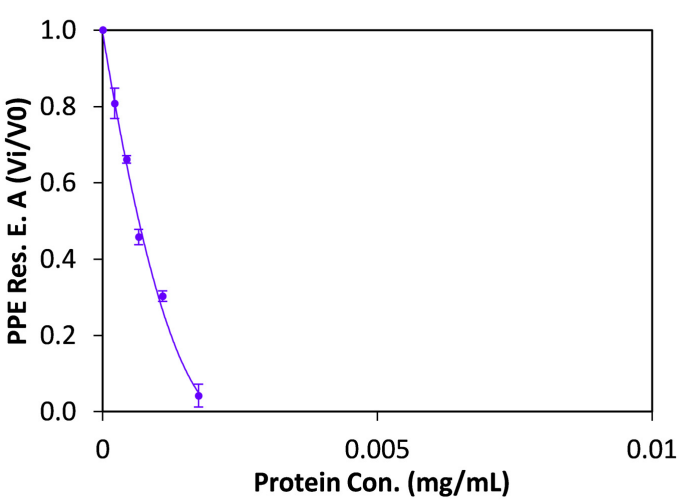

- N. peloronta

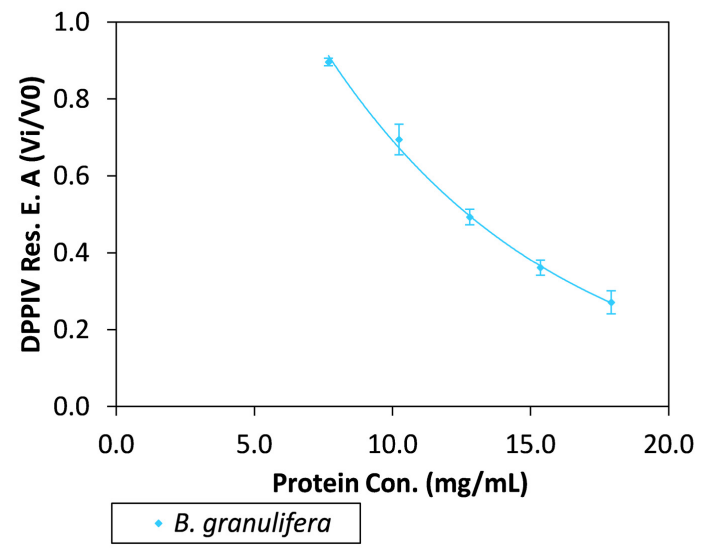

(c)

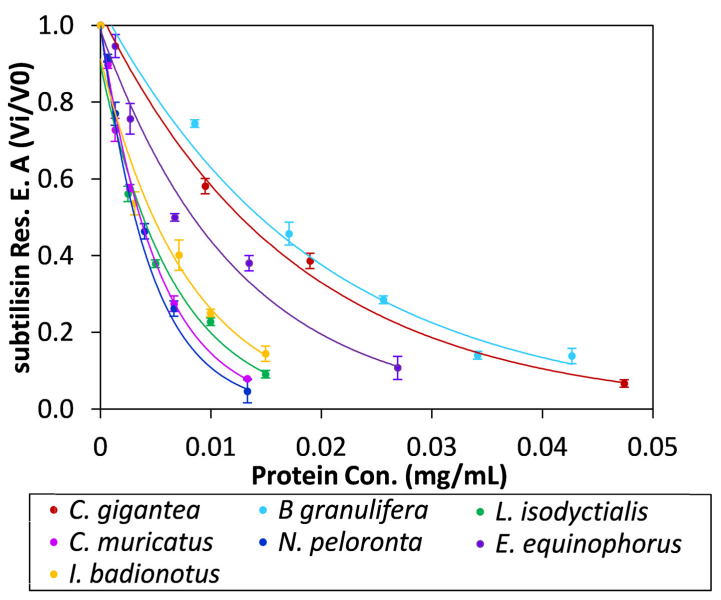

(d)

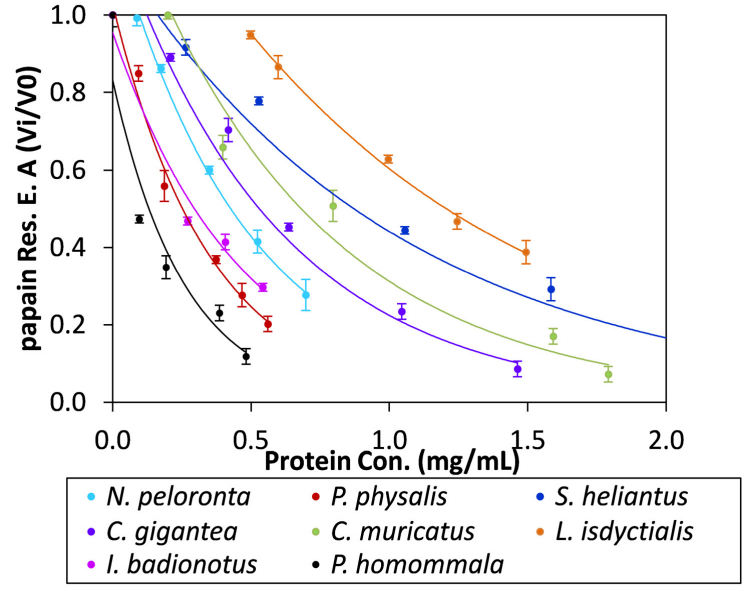

(e)

Figure 1. Dose-response relationships of inhibitory activity against PPE, DPPIV, subtilisin and papain of marine clarified extracts. Effects of different doses of clarified extracts towards the enzyme activity of: (a) (b) PPE, (c) DPPIV, (d) subtilisin and (e) papain. Res. E.A.: Residual Enzymatic Activity. The best-fit value of IC $_{50}$ was performed by adjusting the experimental data to the $\mathrm{IC}_{50}$ equation [37] using the software GraphPad Prism 5.0 (GraphPad Software, Inc., USA). 
Table 3. Results of the screening for DPPIV inhibitory activity in marine invertebrates.

\begin{tabular}{ccccc}
\hline Species & $\begin{array}{c}\text { Protein } \\
\text { concentration } \\
(\mathrm{mg} / \mathrm{ml})\end{array}$ & $\begin{array}{c}\text { Inhibitory activity } \\
(\mathrm{mU} / \mathrm{ml})\end{array}$ & $\begin{array}{c}\text { Specific } \\
\text { inhibitory activity } \\
(\mathrm{mU} / \mathrm{mg})\end{array}$ & $\mathrm{IC}_{50}(\mathrm{mg} / \mathrm{ml})$ \\
\hline Bunodosoma granulifera & $23.5 \pm 0.46$ & $13.59 \pm 2.43$ & 0.58 & $6.6 \pm 1.29$ \\
\hline
\end{tabular}

Data are means $(\mathrm{n}=3) \pm$ S.D.

Table 4. Results of the screening for subtilisin inhibitory activity in marine invertebrates.

\begin{tabular}{ccccc}
\hline Species & $\begin{array}{c}\text { Protein } \\
\text { concentration } \\
(\mathrm{mg} / \mathrm{ml})\end{array}$ & $\begin{array}{c}\text { Inhibitory activity } \\
(\mathrm{mU} / \mathrm{ml})\end{array}$ & $\begin{array}{c}\text { Specific } \\
\text { inhibitory activity } \\
(\mathrm{mU} / \mathrm{mg})\end{array}$ & IC $_{50}(\mathrm{mg} / \mathrm{ml})$ \\
\hline Condylactis gigantea & $18.96 \pm 0.45$ & $3932.58 \pm 110.67$ & 207.41 & $0.010 \pm 0.002$ \\
Bunodosoma granulifera & $51.2 \pm 1.2$ & $14,157.3 \pm 216.54$ & 276.51 & $0.011 \pm 0.002$ \\
Lissodendorix isodyctialis & $4.98 \pm 0.73$ & $4269.66 \pm 143.32$ & 857.36 & $0.003 \pm 0.0002$ \\
Echinaster equinophorus & $26.91 \pm 0.63$ & $26,292.13 \pm 185.78$ & 977.40 & $0.008 \pm 0.0006$ \\
Isostochopus badionotus & $13.56 \pm 0.79$ & $10,669.95 \pm 165.45$ & 786.87 & $0.005 \pm 0.0004$ \\
Cenchritis muricatus & $19.9 \pm 0.43$ & $22,191.01 \pm 264.53$ & 1668.50 & $0.003 \pm 0.0004$ \\
Nerita peloronta & $8.72 \pm 0.64$ & $9737.83 \pm 176.12$ & 556.45 & $0.0031 \pm 0.0004$ \\
\hline
\end{tabular}

Data are means $(n=3) \pm$ S.D.

\subsubsection{Inhibition of Papain and Cathepsin $\mathrm{K}$}

Inhibition activities against these enzymes were first determined by using papain, which is the prototypical cysteine protease and belongs to the same family than cathepsin $\mathrm{K}$. All extracts positive against papain were further tested with the latter enzyme and in all cases the inhibition was confirmed. As shown in Table 5(a), eight extracts were identified, exhibiting quite similar SIA and $\mathrm{IC}_{50}$ values. Even so, the best values of these two parameters were obtained for Physalia physalis and Isostochopus badionotus. The extract of Plexaura homomalla showed the lowest value of $\mathrm{IC}_{50}$ but a poor SIA value. Figure 1 (e) shows the dose-response curves obtained for the positive extracts with this enzyme, which showed a concave behavior characteristic for a reversible inhibition. Similar to the results obtained with papain, the best SIA values against cathepsin $\mathrm{K}$ were exhibited by $P$. physalis, I. badionotus and N. peloronta, (Table 5(b)).

In general, some of the extracts seems to contain several (or unspecific) inhibitors since they showed inhibitory activities against different proteases. For example, Condylactis gigantea, N. peloronta, C. muricatus, I. badionotus and $L$. isodyctialis exhibited inhibition for three of the four enzymes here analyzed (PPE, subtilisin and papain). B. granulifera also exhibited inhibition against three enzymes, however the inhibition observed for DPPIV was rather poor. P. homomalla and S. helianthus showed inhibition against two enzymes, PPE and papain. On the other hand, four of the twenty extracts analyzed showed inhibitory activity only against one of the enzymes tested: Diplosoma listerianum (PPE), P. physalis (papain), Equinaster equinophorus (subtilisin) and Holothuria mexicana (PPE), summarized in Table 1.

\subsection{Proteolytic Activity of the Extracts}

Only one extract (Condylactis gigantea) showed enzymatic activity against two of the chromogenic substrates employed (Suc-Ala-Ala-Ala-pNA and MeOSuc-Ala-Ala-Pro-Val-pNA), which are commonly specific for elastases. This activity was not observed for the clarified extract (data not shown).

\section{Discussion}

Proteolytic enzymes or peptidases are the most abundant enzymes in nature; therefore, proteolytic activity is involved in the whole life cycle of a living organism. Advances in genomics and proteomics have allowed the detection of many proteases, which according to the role they play, constitute therapeutic targets for different systemic and infectious diseases. Consequently, besides the importance of inhibitors as biotechnological and biochemical tools, a new therapeutic strategy based on PI is successfully emerging validated by the efficacy of several 
Table 5. (a) Results of the screening for papain inhibitory activity in marine invertebrates; (b) Cathepsin K inhibitory activity in marine invertebrates.

(a)

\begin{tabular}{ccccc}
\hline Species & $\begin{array}{c}\text { Protein } \\
\text { concentration } \\
(\mathrm{mg} / \mathrm{ml})\end{array}$ & $\begin{array}{c}\text { Inhibitory activity } \\
(\mathrm{mU} / \mathrm{ml})\end{array}$ & $\begin{array}{c}\text { Specific } \\
\text { inhibitory activity } \\
(\mathrm{mU} / \mathrm{mg})\end{array}$ & $\mathrm{IC}_{50}(\mathrm{mg} / \mathrm{ml})$ \\
\hline Stichodactyla helianthus & $26.4 \pm 0.78$ & $112.36 \pm 11.23$ & 4.26 & $0.9 \pm 0.16$ \\
Condylactis gigantea & $20.9 \pm 0.45$ & $106.74 \pm 13.98$ & 5.11 & $0.58 \pm 0.11$ \\
Isostochopus badionotus & $13.56 \pm 0.79$ & $191.01 \pm 24.64$ & 14.09 & $0.25 \pm 0.01$ \\
Cenchritis muricatus & $19.9 \pm 0.43$ & $87.08 \pm 4.57$ & 4.38 & $0.75 \pm 0.16$ \\
Nerita peloronta & $8.72 \pm 0.64$ & $72.1 \pm 3.99$ & 8.38 & $0.48 \pm 0.08$ \\
Lissodendorix isodyctialis & $4.98 \pm 0.73$ & $21.54 \pm 0.56$ & 4.32 & $1.48 \pm 0.32$ \\
Physalia physalis & $9.34 \pm 0.35$ & $188.2 \pm 15.34$ & 20.15 & $0.20 \pm 0.16$ \\
Plexaura homomalla & $96.4 \pm 0.26$ & $449.44 \pm 22.43$ & 4.66 & $0.11 \pm 0.21$ \\
\hline
\end{tabular}

Data are means $(n=3) \pm$ S.D.

(b)

\begin{tabular}{cccc}
\hline Species & $\begin{array}{c}\text { Protein concentration } \\
(\mathrm{mg} / \mathrm{ml})\end{array}$ & $\begin{array}{c}\text { Inhibitory activity } \\
(\mathrm{mU} / \mathrm{ml})\end{array}$ & $\begin{array}{c}\text { Specific } \\
\text { inhibitory activity } \\
(\mathrm{mU} / \mathrm{mg})\end{array}$ \\
\hline Stichodactyla helianthus & $26.4 \pm 0.78$ & 101.12 & 3.83 \\
Condylactis gigantea & $20.9 \pm 0.45$ & 101.12 & 4.84 \\
Isostochopus badionotus & $13.56 \pm 0.79$ & 159.55 & 11.77 \\
Cenchritis muricatus & $19.9 \pm 0.43$ & 78.65 & 3.95 \\
Nerita peloronta & $8.72 \pm 0.64$ & 58.43 & 6.70 \\
Lissodendorix isodyctialis & $4.98 \pm 0.73$ & 12.36 & 2.48 \\
Physalia physalis & $9.34 \pm 0.35$ & 178.5 & 19.13 \\
Plexaura homomalla & $96.4 \pm 0.26$ & 178.65 & 1.85 \\
Stichodactyla helianthus & $26.4 \pm 0.78$ & 101.12 & 3.83 \\
Condylactis gigantea & $20.9 \pm 0.45$ & 101.12 & 4.84 \\
\hline
\end{tabular}

inhibitors already applied as drugs and the high number of many others in different stages of development at lab or at preclinical and clinical trials [12] [40]-[42].

The screening of natural sources is a traditional methodology to identify functional biomolecules including new protease inhibitors with potential applications in Biomedicine and Biotechnology. Considering that approximately $60 \%$ of all drugs developed so far are originally or derived from natural sources and that less than $10 \%$ of the natural biodiversity has been exploited, nowadays this procedure still constitute one of the first choice in this regard [19]. Natural sources contain a remarkable chemical diversity and marine invertebrates are one of the most attractive examples of the largely unexplored marine environment [2]. Moreover, this traditional methodology combined with recent advances in proteomics, bioinformatics and protein engineering provide the tools to detect and improve new therapeutic targets and their inhibitors more efficiently. Several examples illustrates how the combination of natural inhibitors and protein engineering have led to the production of highly selective protease inhibitors [43] [44]. Here we analyzed the potential inhibitory activities of twenty extracts of marine invertebrates from seven different Phyla, against four target proteases with therapeutic relevance. We detected inhibitory activities against all the enzymes assayed, although differences in the rate of inhibition were found to be remarkable among them.

The extracts analyzed were subjected to a heating treatment prior to the screening since this clarification pro- 
cedure has demonstrated before a high effectiveness compared to other methods, such as TCA precipitation [45] [46]. For example, the presence of elastase-like proteolytic activity in the crude extract of $C$. gigantea was eliminated by heating, confirming the efficacy of this method prior to inhibitory activity evaluation. For most of the extracts the protein concentration decreased by almost two times after the heating treatment, however the total inhibitory activity did not change, so the specific inhibitory activity also increased by almost two times. Moreover, many already identified protease inhibitors from marine invertebrates are low molecular weight proteins, resistant to high temperatures, like the assayed in this work [23] [25] [26] [28].

The highest number of positive species (half of the extracts analyzed) were detected when analyzing inhibitory activity against PPE. Elastases form a subfamily of serine proteases that hydrolyze many proteins in addition to elastin, and in particular HNE constitutes an important therapeutic target because of its role in inflammation, respiratory and pulmonary diseases, such as adult respiratory distress, rheumatoid arthritis, pulmonary emphysema, among others [5] [6]. Results obtained in this study with PPE and HNE were in principle expected, since various elastase inhibitors have already been isolated from marine invertebrates. Examples of these are the BPTI-Kunitz inhibitor AXPI-II from the sea anemone Anthopleura xantogrammica [47]; the Kazal inhibitors from the sea anemone Anemonia sulcata [48] [49]; the coral Melithaea caledonica [50]; and the snail C. muricatus [25]. The last one, CmPI-2, was obtained by our group exhibiting high inhibitory activity against elastases and subtilisin. Most of these inhibitors lack specificity or potency, which has forced the search for new molecules. These results here shown offer new sources to isolate new inhibitors against this target. According to the titration behavior in the dose response curve, the extract of $N$. peloronta constitutes a promising source for the identification of tight binding or irreversible inhibitors against HNE.

Regarding DPPIV the screening experiments revealed only one extract (B. granulifera) with inhibitory activity against this enzyme. This extract also exhibited very poor values of SIA (specific inhibitory activity) and IC 50 . In a previous screening experiment against DPPIV, carried out with some of the marine invertebrate extracts analyzed in this study and others, it was observed that only three extracts showed inhibitory activity against the enzyme [46]. The study included the extract of $B$. granulifera with an $\mathrm{IC}_{50}$ value in the same order $(1.2 \mathrm{mg} / \mathrm{mL})$ similar to that obtained in the current study, which also confirms a rather poor value. It is possible that this phenomenon is due to the fact that DPPIV is only produced in mammals with functions more related to complex organisms, such as immune regulation, signal transduction and apoptosis [10].

Results obtained for subtilisin A showed that all positive extracts exhibited $\mathrm{IC}_{50}$ values in the order of $\mu \mathrm{g} / \mathrm{mL}$ and three of them (Lissodendorix isodyctialis, Cenchritis muricatus and Nerita peloronta) displayed dose-response curves with titration behavior, suggesting the presence of tight binding or irreversible inhibitors. It is important to note that in the case of $C$. muricatus, a molecule with inhibitory activity against subtilisin in the submicromolar level, CmPI-2, has been already isolated [25]. Subtilisins are present in many pathogenic microorganisms required within invasion/proliferation processes [7] [8]. Marine invertebrates live alongside many bacteria and parasites in aquatic environments and they protect themselves against pathogenic infection through their innate immune system, which utilizes several biomolecules for their defense including protease inhibitors [22]. Regarding this, many subtilisin inhibitors have been already isolated from these organisms, for example: the Kazal inhibitors SPIPm from Penaeus monodon, PIKPI from Pacifastacus leniusculus, CrSPI from Carcinoscorpius rotundicauda and FcSPI1 from Fenneropenaeus chinensis [51]. However, most of them have a broad specificity against many other serine proteases, which constitutes a challenge within drug development, As for HNE, results obtained in this work revealed other species that could be used as sources for the isolation of new molecules with better properties than those already characterized.

The search for cysteine protease inhibitors has increased in the last years with the importance of these molecules in the life cycles of infectious agents and in physiological and pathological processes of mammals [52]. The presence of cysteine protease inhibitors in marine invertebrates have been previously reported [53] [54], although this source of biomolecules have been less explored. Recently, a fraction enriched in tight-binding protease inhibitors was isolated from the Caribbean coral P. homomalla showing Falcipain 2 and Cruzipain inhibitory activity at the nanomolar level [55]. A high number of extracts screened in this work displayed inhibitory activity against the model enzyme papain, and were further confirmed to inhibit also the therapeutic target cathepsin K. In the case of this particular enzyme none inhibitor molecule coming from marine invertebrates has been reported. It is important to note that one of the extracts showing the best values in terms of SIA and IC ${ }_{50}$ also exhibited specificity only for this enzyme (Physalia physalis). Thus, this extract may constitute the most promising source to isolate an inhibitor with good properties to be employed in future therapeutics. 


\section{Conclusion}

The present work constitutes the first wide report of inhibitory activity against neutrophil elastase and cathepsin $\mathrm{K}$ in extracts from marine invertebrates and the first for the majority of the extracts used against the four enzymes. Further work will be directed to identify and characterize the molecules responsible for the inhibition observed in the most promising extracts of this study, since they may lead and support the development and design of new drugs for the future treatment of several pathological conditions where these enzymes are involved.

\section{Acknowledgements}

This work was supported by project 01 DN 1308 of The Federal Ministry of Education and Research (BMBF). We thank Prof. Dr. Ulrich Hahn from the Institute of Biochemistry and Molecular Biology, University of Hamburg for his contribution to the achievement of this work and Dr. Aida Hernández Zanuy from the Cuban National Institute of Oceanology for technical assistance with the collection and taxonomy of the marine organisms.

\section{References}

[1] Rawlings, N.D., Tolle, D.P. and Barrett, A.J. (2004) Evolutionary Families of Peptidase Inhibitors. Biochemical Journal, 378, 705-716. http://dx.doi.org/10.1042/bj20031825

[2] Turk, B. (2006) Targeting Proteases: Successes, Failures and Future Prospects. Nature Reviews Drug Discovery, 5, 785-799. http://dx.doi.org/10.1038/nrd2092

[3] Abbenante, G. and Fairlie, D.P. (2005) Protease Inhibitors in the Clinic. Medicinal Chemistry, 1, 71-104. http://dx.doi.org/10.2174/1573406053402569

[4] Scott, C.J. and Taggart, C.C. (2010) Biologic Protease Inhibitors as Novel Therapeutic Agents. Biochimie, 92, 16811688. http://dx.doi.org/10.1016/j.biochi.2010.03.010

[5] Korkmaz, B., Horwitz, M.S., Jenne, D.E. and Gauthier, F. (2010) Neutrophil Elastase, Proteinase 3, and Cathepsin G as Therapeutic Targets in Human Diseases. Pharmacological Reviews, 62, 726-759. http://dx.doi.org/10.1124/pr.110.002733

[6] Kawabata, K., Hagio, T. and Matsuoka, S. (2002) The Role of Neutrophil Elastase in Acute Lung Injury. European Journal of Pharmacology, 451, 1-10. http://dx.doi.org/10.1016/S0014-2999(02)02182-9

[7] Windhorst, S., Frank, E., Georgieva, D.N., Genov, N., Buck, F., et al. (2002) The Major Extracellular Protease of the Nosocomial Pathogen Stenotrophomonas maltophilia: Characterization of the Protein and Molecular Cloning of the Gene. Journal of Biological Chemistry, 277, 11042-11049. http://dx.doi.org/10.1074/jbc.M109525200

[8] Alam, A. (2014) Serine Proteases of Malaria Parasite Plasmodium falciparum: Potential as Antimalarial Drug Targets. Interdisciplinary Perspectives on Infectious Diseases, 2014, Article ID: 453186. http://dx.doi.org/10.1155/2014/453186

[9] Zhao, Y., Yang, L. and Zhou, Z. (2014) Dipeptidyl Peptidase-4 Inhibitors: Multitarget Drugs, Not Only Antidiabetes Drugs. Journal of Diabetes, 6, 21-29. http://dx.doi.org/10.1111/1753-0407.12063

[10] Patel, B.D. and Ghate, M.D. (2014) Recent Approaches to Medicinal Chemistry and Therapeutic Potential of Dipeptidyl Peptidase-4 (DPP-4) Inhibitors. European Journal of Medicinal Chemistry, 74, 574-605. http://dx.doi.org/10.1016/j.ejmech.2013.12.038

[11] Costa, A.G., Cusano, N.E., Silva, B.C., Cremers, S. and Bilezikian, J.P. (2011) Cathepsin K: Its Skeletal Actions and Role as a Therapeutic Target in Osteoporosis. Nature Reviews Rheumatology, 7, 447-456. http://dx.doi.org/10.1038/nrrheum.2011.77

[12] Bromme, D. and Lecaille, F. (2009) Cathepsin K Inhibitors for Osteoporosis and Potential Off-Target Effects. Expert Opinion on Investigational Drugs, 18, 585-600. http://dx.doi.org/10.1517/13543780902832661

[13] Zaqueo, K.D., Kayano, A.M., Simoes-Silva, R., Moreira-Dill, L.S., Fernandes, C.F., et al. (2014) Isolation and Biochemical Characterization of a New Thrombin-Like Serine Protease from Bothrops pirajai Snake Venom. BioMed Research International, 2014, Article ID: 595186. http://dx.doi.org/10.1155/2014/595186

[14] Mukherjee, A.K. and Mackessy, S.P. (2013) Biochemical and Pharmacological Properties of a New Thrombin-Like Serine Protease (Russelobin) from the Venom of Russell's Viper (Daboia russelii russelii) and Assessment of Its Therapeutic Potential. Biochimica et Biophysica Acta, 1830, 3476-3488. http://dx.doi.org/10.1016/j.bbagen.2013.02.007 
[15] Bekes, M., Rut, W., Kasperkiewicz, P., Mulder, M.P., Ovaa, H., et al. (2015) SARS hCoV Papain-Like Protease Is a Unique Lys ${ }^{48}$ Linkage-Specific Di-Distributive Deubiquitinating Enzyme. Biochemical Journal, 468, 215-226. http://dx.doi.org/10.1042/BJ20141170

[16] Ksiazek, M., Karim, A.Y., Bryzek, D., Enghild, J.J., Thogersen, I.B., et al. (2015) Mirolase, a Novel Subtilisin-Like Serine Protease from the Periodontopathogen Tannerella forsythia. Biological Chemistry, 396, 261-275. http://dx.doi.org/10.1515/hsz-2014-0256

[17] Montaser, R. and Luesch, H. (2011) Marine Natural Products: A New Wave of Drugs? Future Medicinal Chemistry, 3, 1475-1489.

[18] Leung, D., Abbenante, G. and Fairlie, D.P. (2000) Protease Inhibitors: Current Status and Future Prospects. Journal of Medicinal Chemistry, 43, 305-341. http://dx.doi.org/10.1021/jm990412m

[19] Cragg, G.M. and Newman, D.J. (2013) Natural Products: A Continuing Source of Novel Drug Leads. Biochimica et Biophysica Acta, 1830, 3670-3695. http://dx.doi.org/10.1016/j.bbagen.2013.02.008

[20] Xue, Q., Itoh, N., Schey, K.L., Cooper, R.K. and La Peyre, J.F. (2009) Evidence Indicating the Existence of a Novel Family of Serine Protease Inhibitors That May Be Involved in Marine Invertebrate Immunity. Fish and Shellfish Immunology, 27, 250-259. http://dx.doi.org/10.1016/j.fsi.2009.05.006

[21] Molinski, T.F., Dalisay, D.S., Lievens, S.L. and Saludes, J.P. (2009) Drug Development from Marine Natural Products. Nature Reviews Drug Discovery, 8, 69-85. http://dx.doi.org/10.1038/nrd2487

[22] Iwanaga, S. and Lee, B.L. (2005) Recent Advances in the Innate Immunity of Invertebrate Animals. BMB Reports, 38, 128-150. http://dx.doi.org/10.5483/BMBRep.2005.38.2.128

[23] Pascual, I., Gil-Parrado, S., Cisneros, M., Joseph-Bravo, P., Diaz, J., et al. (2004) Purification of a Specific Inhibitor of Pyroglutamyl Aminopeptidase II from the Marine Annelide Hermodice carunculata: In Vivo Effects in Rodent Brain. The International Journal of Biochemistry \& Cell Biology, 36, 138-152. http://dx.doi.org/10.1016/S1357-2725(03)00175-4

[24] Lopez-Abarrategui, C., Alba, A., Silva, O.N., Reyes-Acosta, O., Vasconcelos, I.M., et al. (2012) Functional Characterization of a Synthetic Hydrophilic Antifungal Peptide Derived from the Marine Snail Cenchritis muricatus. Biochimie, 94, 968-974. http://dx.doi.org/10.1016/j.biochi.2011.12.016

[25] Gonzalez, Y., Tanaka, A.S., Hirata, I.Y., del Rivero, M.A., Oliva, M.L., et al. (2007) Purification and Partial Characterization of Human Neutrophil Elastase Inhibitors from the Marine Snail Cenchritis muricatus (Mollusca). Comparative Biochemistry and Physiology Part A: Molecular \& Integrative Physiology, 146, 506-513. http://dx.doi.org/10.1016/j.cbpa.2006.01.022

[26] Delfin, J., Martinez, I., Antuch, W., Morera, V., Gonzalez, Y., et al. (1996) Purification, Characterization and Immobilization of Proteinase Inhibitors from Stichodactyla helianthus. Toxicon, 34, 1367-1376. http://dx.doi.org/10.1016/S0041-0101(96)00114-6

[27] Alvarez, C., Mancheno, J.M., Martinez, D., Tejuca, M., Pazos, F., et al. (2009) Sticholysins, Two Pore-Forming Toxins Produced by the Caribbean Sea Anemone Stichodactyla helianthus: Their Interaction with Membranes. Toxicon, 54, 1135-1147. http://dx.doi.org/10.1016/j.toxicon.2009.02.022

[28] Alonso-del-Rivero, M., Trejo, S.A., Reytor, M.L., Rodriguez-de-la-Vega, M., Delfin, J., et al. (2012) Tri-Domain Bifunctional Inhibitor of Metallocarboxypeptidases A and Serine Proteases Isolated from Marine Annelid Sabellastarte magnifica. Journal of Biological Chemistry, 287, 15427-15438. http://dx.doi.org/10.1074/jbc.M111.337261

[29] Pascual, I., Gomez, H., Pons, T., Chappe, M., Vargas, M.A., et al. (2011) Effect of Divalent Cations on the Porcine Kidney Cortex Membrane-Bound form of Dipeptidyl Peptidase IV. The International Journal of Biochemistry \& Cell Biology, 43, 363-371. http://dx.doi.org/10.1016/j.biocel.2010.11.006

[30] Scopes, R.K. (1987) Protein Purification: Principles and Practice. 2nd Edition, Springer-Verlag, New York.

[31] Sober, H.A., Harte, R.A. and Sober, E.K. (1968) Handbook of Biochemistry: Selected Data for Molecular Biology. Chemical Rubber Company CRC, Cleveland.

[32] Nakajima, K., Powers, J.C., Ashe, B.M. and Zimmerman, M. (1979) Mapping the Extended Substrate Binding Site of Cathepsin G and Human Leukocyte Elastase. Studies with Peptide Substrates Related to the Alpha 1-Protease Inhibitor Reactive Site. The Journal of Biological Chemistry, 254, 4027-4032.

[33] DelMar, E.G., Largman, C., Brodrick, J.W. and Geokas, M.C. (1979) A Sensitive New Substrate for Chymotrypsin. Analytical Biochemistry, 99, 316-320. http://dx.doi.org/10.1016/S0003-2697(79)80013-5

[34] Nagatsu, T., Hino, M., Fuyamada, H., Hayakawa, T. and Sakakibara, S. (1976) New Chromogenic Substrates for X-Prolyl Dipeptidyl-Aminopeptidase. Analytical Biochemistry, 74, 466-476. http://dx.doi.org/10.1016/0003-2697(76)90227-X

[35] Tchoupe, J.R., Moreau, T., Gauthier, F. and Bieth, J.G. (1991) Photometric or Fluorometric Assay of Cathepsin B, L 
and $\mathrm{H}$ and Papain Using Substrates with an Aminotrifluoromethylcoumarin Leaving Group. Biochimica et Biophysica Acta, 1076, 149-151. http://dx.doi.org/10.1016/0167-4838(91)90232-O

[36] Falgueyret, J.P., Oballa, R.M., Okamoto, O., Wesolowski, G., Aubin, Y., et al. (2001) Novel, Nonpeptidic Cyanamides as Potent and Reversible Inhibitors of Human Cathepsins K and L. Journal of Medicinal Chemistry, 44, 94-104. http://dx.doi.org/10.1021/jm0003440

[37] Copeland, R.A., Lombardo, D., Giannaras, J. and Decicco, C.P. (1995) Estimating KI Values for Tight Binding Inhibitors from Dose-Response Plots. Bioorganic \& Medicinal Chemistry Letters, 5, 1947-1952. http://dx.doi.org/10.1016/0960-894X(95)00330-V

[38] Motulsky, H. (2007) Prism 5 Statistics Guide. GraphPad Software, San Diego.

[39] Bieth, J.G. (1995) Theoretical and Practical Aspects of Proteinase Inhibition Kinetics. Methods in Enzymology, 248, 59-84. http://dx.doi.org/10.1016/0076-6879(95)48007-2

[40] Tagami, T., Tosa, R., Omura, M., Fukushima, H., Kaneko, T., et al. (2014) Effect of a Selective Neutrophil Elastase Inhibitor on Mortality and Ventilator-Free Days in Patients with Increased Extravascular Lung Water: A Post Hoc Analysis of the PiCCO Pulmonary Edema Study. Journal of Intensive Care, 2, 67. http://dx.doi.org/10.1186/s40560-014-0067-y

[41] Yamazaki, S., Takayama, T., Moriguchi, M., Hayashi, Y., Mitsuka, Y., et al. (2015) Neutrophil Elastase Inhibitor Following Liver Resection: A Matched Cohort Study. Hepatitis Monthly, 15, e31235. http://dx.doi.org/10.5812/hepatmon.31235

[42] Stoch, S.A., Zajic, S., Stone, J.A., Miller, D.L., van Bortel, L., et al. (2013) Odanacatib, a Selective Cathepsin K Inhibitor to Treat Osteoporosis: Safety, Tolerability, Pharmacokinetics and Pharmacodynamics-Results from Single Oral Dose Studies in Healthy Volunteers. British Journal of Clinical Pharmacology, 75, 1240-1254. http://dx.doi.org/10.1111/j.1365-2125.2012.04471.x

[43] Stoop, A.A. and Craik, C.S. (2003) Engineering of a Macromolecular Scaffold to Develop Specific Protease Inhibitors. Nature Biotechnology, 21, 1063-1068. http://dx.doi.org/10.1038/nbt860

[44] Levy, J.H. and O’Donnell, P.S. (2006) The Therapeutic Potential of a Kallikrein Inhibitor for Treating Hereditary Angioedema. Expert Opinion on Investigational Drugs, 15, 1077-1090.

http://dx.doi.org/10.1517/13543784.15.9.1077

[45] Reytor, M.L., González, Y., Pascual, I., Hernández, A., Chávez, M.A., et al. (2011) Screening of Protease Inhibitory Activity in Extracts of Five Ascidian Species from Cuban Coasts. Biotecnología Aplicada, 28, 77-82.

[46] Pascual, I., Lopéz, A., Gómez, H., Chappé, M., Saroyán, A., et al. (2007) Screening of Inhibitors of Porcine Dipeptidyl Peptidase IV Activity in Aqueous Extracts from Marine Organisms. Enzyme and Microbial Technology, 40, 414-419. http://dx.doi.org/10.1016/j.enzmictec.2006.07.012

[47] Minagawa, S., Ishida, M., Shimakura, K., Nagashima, Y. and Shiomi, K. (1997) Isolation and Amino Acid Sequences of Two Kunitz-Type Protease Inhibitors from the Sea Anemone Anthopleura aff. xanthogrammica. Comparative Biochemistry and Physiology Part B: Biochemistry and Molecular Biology, 118, 381-386. http://dx.doi.org/10.1016/S0305-0491(97)00174-0

[48] Tschesche, H., Kolkenbrock, H. and Bode, W. (1987) The Covalent Structure of the Elastase Inhibitor from Anemonia sulcata-A “Non-Classical” Kazal-Type Protein. Biological Chemistry, 368, 1297-1304. http://dx.doi.org/10.1515/bchm3.1987.368.2.1297

[49] Hemmi, H., Kumazaki, T., Yoshizawa-Kumagaye, K., Nishiuchi, Y., Yoshida, T., et al. (2005) Structural and Functional Study of an Anemonia Elastase Inhibitor, a "Nonclassical” Kazal-Type Inhibitor from Anemonia sulcata. Biochemistry, 44, 9626-9636. http://dx.doi.org/10.1021/bi0472806

[50] La Barre, S., Longeon, A., Barthelemy, M., Guyot, M., Le Caer, J.P., et al. (1996) Characterization of a Novel Elastase Inhibitor from a Fan Coral. Comptes Rendus de l'Académie des Sciences-Series III, 319, 365-370.

[51] Rimphanitchayakit, V. and Tassanakajon, A. (2010) Structure and Function of Invertebrate Kazal-Type Serine Proteinase Inhibitors. Developmental \& Comparative Immunology, 34, 377-386. http://dx.doi.org/10.1016/j.dci.2009.12.004

[52] Vicik, R., Busemann, M., Baumann, K. and Schirmeister, T. (2006) Inhibitors of Cysteine Proteases. Current Topics in Medicinal Chemistry, 6, 331-353. http://dx.doi.org/10.2174/156802606776287081

[53] Nakao, Y., Fujita, M., Warabi, K., Matsunaga, S. and Fusetani, N. (2000) Miraziridine A, a Novel Cysteine Protease Inhibitor from the Marine Sponge Theonella aff. mirabilis. Journal of the American Chemical Society, 122, 1046210463. http://dx.doi.org/10.1021/ja001859j

[54] Fusetani, N., Fujita, M., Nakao, Y., Matsunaga, S. and Van Soest, R.W. (1999) Tokaramide A, a New Cathepsin B Inhibitor from the Marine Sponge Theonella aff. mirabilis. Bioorganic \& Medicinal Chemistry Letters, 9, 3397-3402. 
http://dx.doi.org/10.1016/S0960-894X(99)00618-6

[55] Salas-Sarduy, E., Cabrera-Munoz, A., Cauerhff, A., Gonzalez-Gonzalez, Y., Trejo, S.A., et al. (2013) Antiparasitic Effect of a Fraction Enriched in Tight-Binding Protease Inhibitors Isolated from the Caribbean Coral Plexaura homomalla. Experimental Parasitology, 135, 611-622. http://dx.doi.org/10.1016/j.exppara.2013.09.013 